\title{
KOTIMAISTA KUNTOUTUKSEN TUTKIMUSTA TARVITAAN
}

\section{PÄÄKIRJOITUS}

ERJA POUTIAINEN
Tieteelliseen tutkimukseen suhtaudutaan Suomessa joskus kaksijakoisesti. Saatetaan pohtia, onko tieteelliseen tutkimukseen perustuva tiedontuotanto tarpeellista ja kannattaako sitä tukea. Toisaalta edellytetään, että esimerkiksi sosiaali- ja terveydenhuollon toimenpiteet perustuvat tutkittuun tietoon niiden vaikuttavuudesta. Näitä viestejä voi tulkita niinkin, että valmis, usein muissa maissa tuotettu tutkimustieto otetaan mielellään käyttöön, vaikka oman tutkimustoiminnan resursointiin ei koettaisi tarvetta. Kansainvälisesti tuotetun tutkimustiedon soveltaminen oman maan oloihin ei kuitenkaan ole aina helppoa tai edes mahdollista. Tämä on erityisen hankalaa ihmistieteellisessä, kuten käyttäytymis- tai yhteiskuntatieteellisessä, tutkimuksessa. Tälle alueelle sijoittuu tyypillisesti myös kuntoutuksen tutkimus.

Kuntoutuksen toimenpiteet tulee soveltaa kuntoutujan konkreettisiin työja toimintakyvyn sekä elämänympäristössä toimimisen tavoitteisiin, toisin sanoen suomalaiseen yhteiskuntaan ja kotimaisiin käytäntöihin sopiviksi toimenpiteiksi. Siksi tarvitaan tutkimustietoa Suomessa toteutettujen kuntoutustoimenpiteiden vaikutuksista ja kuntoutumisen prosessin toimivuudesta omassa järjestelmässämme.

Tämän vuoden marraskuussa Kuntoutuksen tutkimus- ja kehittämisyhdistys Kutke ry:n yhdessä THL:n kanssa toteuttama, osallistujamäärän perusteella suosittu kuntoutuksen tutkimusseminaari osoitti hienosti, että emme ole vain kansainvälisen tiedon varassa, vaan suomalainen kuntoutusalan tutkimus on voimissaan. Seminaarissa oli mahdollista tutustua yli 50 korkeatasoiseen, hyvinkin eri tavoin kuntoutuksen tutkimusta lähestyvään esitelmään. Esitykset vahvistivat käsitystä siitä, että Suomessa tehdään omaan yhteiskuntaamme suoraan soveltuvaa kuntoutuksen tutkimusta.

Tutkittu tieto tulee levittää kuntoutusammattilaisten ja päättäjien tietoon. Tutkimusseminaarit ja kongressit ovat tärkeitä tiedon leviämisen paikkoja. Niin ikään viimeisimpään tietoon perustuvat teokset, kuten juuri ilmestynyt Kuntoutuminen-kirja, ovat merkittäviä tiedon levittämisen välineitä.

Myös tieteellis-ammatillisilla julkaisuilla, kuten käsissäsi olevalla Kuntoutus-lehdellä, on merkittävä tutkimustiedon levittämisen tehtävä. Tässäkin numerossa julkaistaan kuntoutuksen kannalta tärkeitä vertaisarvioituja alkuperäistutkimuksia. Näissä artikkeleissa käsitellään työuupumisesta toipumista ja asumispalvelujen yhteistoiminnallista mallia. Lehti julkaisee myös ammatillisesti tärkeitä kirjoituksia, joista esimerkkeinä tämän lehden traumaattisen surun jälkeisen työhönpaluun näkökulmia valottava katsaus ja laajasti kuntoutuksen aihealueille sijoittuvat hanke-esittely ja lectio praecursoria. Koulutusesittelysarjassa on vuorossa toimintaterapiakoulutus. Lehden tavoitteena on lisätä ajankohtaisia aiheita käsitteleviä lyhyitä kirjoituksia. Lukijoita kannustetaankin kirjoittamaan lehteen myös tällaisia kirjoituksia sekä esittelyjä kiinnostavista kuntoutuksen alan kirjoista.

Oikein miellyttävää joulunalusaikaa ja vuodenvaihdetta Kuntoutus-lehden lukijoille! 